\title{
ASSESSING THE IMPORTANCE OF CUTTHROAT Trout TO RIVER OTTERS IN YelLOWSTONE LAKE
}

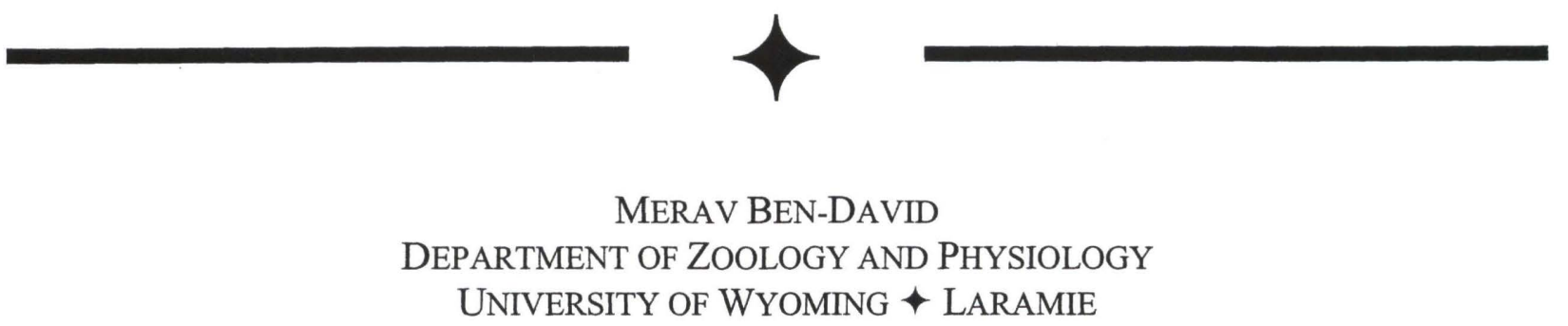

\section{$\downarrow$ ABSTRACT}

Recently-introduced exotic stressors, lake trout (Salvelinus namaycush) and whirling disease (caused by the Myxobolus cerebralis parasite), threaten the native cutthroat trout (Oncorhynchus clarki bouvieri) population in Yellowstone Lake. A reduction in cutthroat-availability may affect fish predators negatively, especially during cutthroat spawning. In this study we examined the importance of spawning cutthroat trout to a fish specialist - the river otter (Lontra canadensis). We measured scentmarking rates at 87 otter latrine sites on Yellowstone Lake and its tributary streams throughout the cutthroat spawning period and identified prey items in scats collected at these sites. Based on fecal deposition rates, otters were more active on spawning streams and less active on Yellowstone Lake during the height of the cutthroat spawning season, with a return to elevated activity on the lake after spawning had ended. Cutthroat trout appeared to be the most common prey item in otter scats throughout the study, based on 515 samples identified to the familylevel and 110 samples analyzed to the species-level. Overall, trout occurred in $72 \%$ and longnose suckers (Catostomus catostomus) in $43 \%$ of otter feces. Suckers were more prevalent than trout in otter scats only on tributary streams, towards the end of the cutthroat spawning run. Introduced lake trout, which inhabit deep water and are largely inaccessible to otters, occurred in less than $5 \%$ of otter scats. River otters in the Yellowstone Lake system appear to be highly restricted in their diet and are heavily dependent on cutthroat trout. Our findings suggest that continued declines in the cutthroat trout population could negatively impact otters, potentially disrupting their role in linking the aquatic and terrestrial systems of Yellowstone Lake.

\section{$\downarrow \quad$ INTRODUCTION}

Yellowstone National Park (YNP) supports the largest remaining population of Yellowstone cutthroat trout (Oncorhynchus clarki bouvieri) and composes up to $91 \%$ of the current geographic range of this subspecies (Varley and Gresswell 1988; Gresswell 1995; Gresswell and Liss 1995). The park's largest body of water, Yellowstone Lake, represents nearly $80 \%$ of the remaining lacustrine habitat for Yellowstone cutthroat trout (Gresswell et al. 1994). In addition to their socioeconomic value as a sport fish and tourist attraction (Gresswell and Liss 1995; Varley and Schullery 1995), these animals are a key food source for a number of avian and mammalian predators (Schullery and Varley 1995; Kaeding et al. 1996; Stapp and Hayward 2002a; Ruzycki et al. 2003). An estimated 42 species prey on or scavenge cutthroat trout in Yellowstone Lake (Schullery and Varley 1995; Varley and Schullery 1998), including bald eagles (Haleaeetus leucocephalus-Davenport 1974; Swenson et al. 1986; McEneaney 2002), brown bears (Ursus arctos-Reinhart and Mattson 1990; Mattson et al. 1991; Mattson and Reinhart 1995; Reinhart et al. 2001; Felicetti et al. 2004), osprey (Pandion haliaetus-Davenport 1974; Swenson 1978; McEneaney 2002), white pelicans (Pelecanus erythrorhynchos-Davenport 1974; McEneaney 2002; Kaeding 2002), and river otters (Lontra 
canadensis-Schullery and Varley 1995; Varley 1998; Johnson and Crabtree 1999; Stapp and Hayward 2002a). Although several of these animals feed on cutthroat throughout the year, the availability of cutthroat trout to piscivores increases from late spring through summer when cutthroat make annual spawning migrations from the lake into tributary streams (Schullery and Varley 1995; Varley and Schullery 1996). While present in shallow water sections of these streams, spawning cutthroat trout are a readily accessible, energy-rich prey item for terrestrial and semi-aquatic predators (Pritchard and Robbins 1990; Mattson and Reinhart 1995; Schullery and Varley 1995; Varley and Schullery 1996; Felicetti et al. 2004).

In recent years, however, two nonindigenous stressors, introduced lake trout (Salvelinus namaycush) and whirling disease (caused by the Myxobolus cerebralis parasite) have contributed to an apparent decline of the cutthroat trout population in Yellowstone Lake (Koel et al. 2004; Koel et al., in press). Population models developed by McIntyre (1995) and Stapp and Hayward (2002b) to predict the effect of the lake trout introduction have estimated that, without management control, lake trout could reduce the native cutthroat trout population by $60-70 \%$ within 100 years. In addition, Ruzycki et al. (2003) estimated that consumption of cutthroat trout could exceed production within 25 years. Such a population reduction raises concerns, not only for the viability of cutthroat trout, but for those components of the Yellowstone Lake food web that rely on them (Schullery and Varley 1995; Stapp and Hayward 2002a; Koel et al., in press). This decline could severely limit the availability of cutthroat trout to piscivorous predators along spawning streams and in Yellowstone Lake (Schullery and Varley 1995). For example, Clear Creek, one of the lake's tributaries, sustained a $90 \%$ decrease in the number of upstream migrating cutthroat trout from 1999 to 2004 (Koel et al., in press).

In this study we assessed the risks of a declining cutthroat trout population to a representative fish predator - the river otter. While it has been speculated that the otter population of Yellowstone Lake could be impacted by a reduction in cutthroat trout numbers (Schullery and Varley 1995; Buskirk 1999; Johnson and Crabtree 1999; Koel et al. 2004), little information exists on otter foraging behavior and their reliance on cutthroat trout in YNP (Varley 1998; Buskirk 1999). As semiaquatic fish specialists (Melquist et al. 2003), otters are relatively restricted in their ability to move to different watersheds in search of food (in contrast with avian predators) or to switch to a non-piscine diet (in contrast to generalist and omnivorous predators). For a cutthroat-dependent otter population, a significant reduction in numbers of these fish will likely result in changes in behavior, and possibly a decline in number of otters, making river otters a reliable indicator species for changes in the population status of cutthroat trout.

Although otters in YNP are known to feed on cutthroat trout (Schullery and Varley 1995; Varley 1998; Stapp and Hayward 2002a; W. Wengeler and R. Landis, pers. comm), the relative contribution of these fish to their diets has yet to be determined. River otters are opportunistic feeders and usually capture fish species in direct proportion to their abundance and density, and in inverse proportion to their swimming ability (Ryder 1955; Toweill 1974; Serfass et al. 1990; Larivière and Walton 1998; Melquist et al. 2003). Several studies of the diet of otters have documented a preponderance of slowmoving, less agile fishes such as those from the families Catostomidae and Cyprinidae, and comparatively fewer agile fish, such as those in the family Salmonidae (Lagler and Ostenson 1942; Ryder 1955; Knudsen and Hale 1968; Zackheim 1982; Serfass et al. 1990; Reid et al. 1994a). In Yellowstone Lake, slow-moving fish species such as the longnose sucker (Catostomus catostomus) may form an important prey base for otters (Schullery and Varley 1995; Johnson and Crabtree 1999; R. Landis, pers. comm). Like cutthroat trout, longnose suckers grow to a large size (up to $61 \mathrm{~cm}$; Baxter and Stone 1995), are obligate stream spawners (Brown and Graham 1954; Varley and Schullery 1998), and inhabit the shallower littoral zone of Yellowstone Lake (Kaeding et al. 1996; Varley and Schullery 1998). Nonetheless, the energy density of cutthroat trout $(5764 \mathrm{~J} / \mathrm{g})$ exceeds that of longnose suckers (4186 J/g; Hanson et al. 1997; Ruzycki et al. 2003), making trout an energetically more beneficial food source for otters when both species are similarly accessible. Indeed, other studies have documented otters making seasonal movements to salmonid spawning grounds to take advantage of the increased availability of this energy-rich prey (Toweill 1974; Melquist and Hornocker 1983; Reid et al. 1994a, b; Melquist et al. 2003).

Although introduced lake trout are lipid-rich salmonids as well (5699 J/g; Stewart et al. 1983; Ruzycki et al. 2003), they are unlikely to be a suitable replacement food source for river otters (Schullery and Varley 1995; Stapp and Hayward 2002b; Ruzycki et al. 2003). Lake trout are largely 
found in deep water (up to $40 \mathrm{~m}$; Kaeding et al. 1996; Koel et al., in press), beyond the foraging depth range of otters (Reid et al. 1994a; Ben-David et al. 2000). In addition, lake trout spawn in lentic waters rather than in tributary streams (Schullery and Varley 1995; Varley and Schullery 1998; Stapp and Hayward 2002b; Ruzycki et al. 2003; Quist and Hubert 2004). Therefore, lake trout should be unavailable to otters during much of the year and appear infrequently in their diets (Schullery and Varley 1995; Varley and Schullery 1998; Koel et al. 2004).

To examine the importance of cutthroat trout to river otters during the spawning season, we investigated rates of scent-marking at river otter latrine sites around Yellowstone Lake and on its tributary streams and performed diet analyses on scats collected at those sites. A comparatively social mustelid (Melquist and Hornocker 1983; Larivière and Walton 1998; Blundell et al. 2002), river otters establish latrine sites for intra-specific communication, at which they deposit feces, urine, and anal gland excretions (Melquist and Hornocker 1983; Ben-David et al. 1998; Swimley et al. 1998). Latrines are typically $5-20 \mathrm{~m}$ in radius and are associated with features such as large conifers, lagoons, rock formations, and sand bars (Melquist and Hornocker 1983; Bowyer et al. 1995, 2003; Swimley et al. 1998; Crait 2005). Often, latrines with the highest marking rates are associated with "activity centers" such as feeding sites and dens (Melquist and Hornocker 1983; Swimley et al. 1998) and thus provide a tool to monitor changes in the activity of otters in relation to migration of cutthroat trout before, during, and following the spawning season.

We hypothesized that otter activity at latrine sites, as determined from fecal deposition rate, would decrease along the Yellowstone Lake shoreline and increase on tributary streams during the cutthroat trout spawning season because otters move from the lake to streams in response to the availability of this prey resource. This trend would be reversed at the end of the spawning season. We further hypothesized that cutthroat trout remains would appear more frequently in scats collected at otter latrines found along tributary streams, than alternative prey, such as longnose suckers and minnows, because cutthroat trout constitute a higher quality food (Stewart et al. 1983; Hanson et al. 1997; Ruzycki et al. 2003). Finally, we hypothesized that lake trout would occur infrequently in otter scats because lake trout are found at depths beyond the diving capabilities of river otters (Reid et al. 1994a; Ben-David et al. 2000).

\section{MATERIALS AND METHODS}

Study area.-Our study area included the shoreline of Yellowstone Lake and its associated tributary streams, located in southeastern Yellowstone National Park, Wyoming, USA (center of park at $44^{\circ} 36^{\prime} \mathrm{N}, 110^{\circ} 30^{\prime} \mathrm{W}$; Fig. 1). The region has a temperate climate characterized by short summers and long, cold winters (Despain 1990). Average annual temperature is $0^{\circ} \mathrm{C}$ and summer and winter temperatures average $11.1^{\circ} \mathrm{C}$ and $-10.8^{\circ} \mathrm{C}$, respectively. Annual precipitation averages $513 \mathrm{~mm}$ and primarily falls as snow in late fall and winter (Benson 1961). The growing season in the area is short (Gresswell et al. 1994), extending from approximately June to September. Terrestrial vegetation is predominately lodgepole pine (Pinus contorta) and subalpine meadows in the uplands, with willow-dominated (Salix spp.) riparian zones. In more mesic habitats, such as north-facing slopes, Engelmann spruce (Picea engelmannii) and subalpine fir (Abies lasiocarpa) communities may dominate (Despain 1990; Marston and Anderson 1991; Knight 1994).

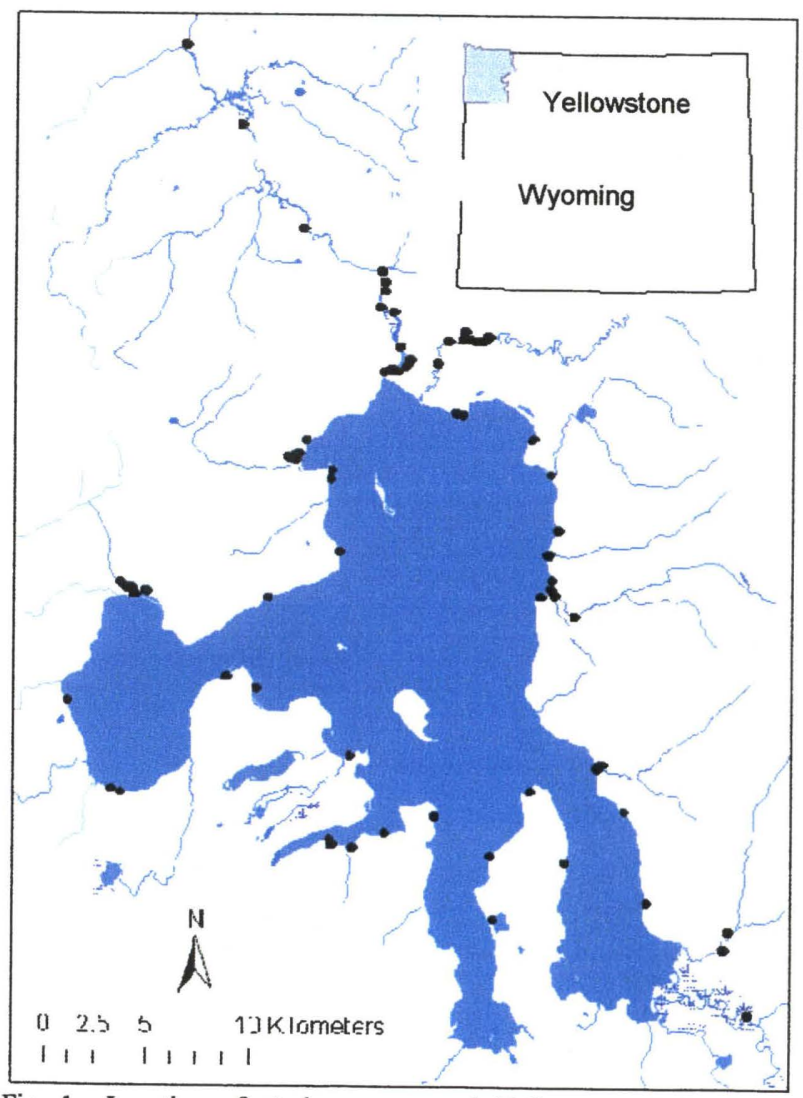

Fig. 1 Location of study area around Yellowstone Lake, in Yellowstone National Park, Wyoming. Dots represent river otter latrine sites sampled in summer 2002 and 2003. 
Yellowstone Lake is a deep $(\overline{\mathrm{x}}=43 \mathrm{~m})$, oligotrophic lake, ice-covered from December through May (Gresswell and Varley 1988). The lake is located at $2357 \mathrm{~m}$ in the Yellowstone Plateau. With a surface area of $341 \mathrm{~km}^{2}$ and shoreline length of $239 \mathrm{~km}$ (Kaplinski 1991), Yellowstone Lake is considered the largest high-elevation lake in North America (Gresswell et al. 1997). The lake's fish species include, two salmonids, Yellowstone cutthroat trout and lake trout, a catostomid; the longnose sucker, and three cyprinids; longnose dace (Rhinichthys cataractae), redside shiners (Richardsonius balteatus), and lake chubs (Couesius plumbeus). Only cutthroat trout and longnose dace are native to the lake (Varley and Schullery 1998).

Yellowstone Lake has 124 tributary streams, the largest of which, the Yellowstone River, drains $42 \%$ of the watershed. Cutthroat trout spawn in approximately 68 of these tributaries, with the peak of the spawn occurring from late May through July (Jones et al. 1987; Gresswell and Varley 1988; Varley and Gresswell 1988; Gresswell et al. 1997). Tributary streams surveyed during our study included sections of the Yellowstone River inlet, the Yellowstone River from the lake's outlet to the Upper Falls of the Yellowstone River; Pelican, Sedge, Cub, Clear, Columbine, Beaver Dam, Otter, Bridge, and Arnica Creeks. We also surveyed the perimeter of Yellowstone Lake, with the exception of restricted, non-motorized zones in the southern portion of the lake.

Sampling design.--Systematic surveys for river otter signs were conducted from 11 June to 7 August 2002 and from 23 May to 15 August 2003. These survey dates were designed to investigate latrine site use by otters throughout the cutthroat trout spawning period; early-spawning, peak-spawning, and following the end of spawning runs. In 2002, because of logistical constraints, surveys of the lakeshore in roadless areas were delayed until 11 July. In 2003, stream and lakeshore surveys started on 23 May.

Designations of early-, peak-, and postspawning periods were based on counts of spawning cutthroat trout from fish weirs on Arnica and Clear Creeks, dip netting on the Yellowstone River (B. Ertel, pers. comm), and our own walking counts along smaller streams (e.g., Cub and Columbine Creeks). For some tributaries, such as Pelican Creek, few recent data were available. In these instances, we designated survey periods based on historical records of average peak spawning dates (Ball and Cope 1961; Gresswell et al. 1994, 1997).
Two factors may have influenced our ability to match survey dates with the spawning schedule of cutthroat trout in tributary streams. First, the initiation of spawning may vary between tributaries of Yellowstone Lake (Gresswell et al. 1994, 1997). For example, the peak of the cutthroat run is usually earlier on Arnica and Bridge Creeks than other streams in our study. Secondly, several tributaries show multiple "peaks" of spawners (Ball and Cope 1961). Thus, on streams with few or no fish present, an apparent early-spawning period may have actually been a lull between peaks. Therefore, it is possible that some survey dates labeled as early-spawning overlapped with the peak of cutthroat spawning.

Given these differences, and variation in spawning schedule of cutthroat trout, we designated our surveys as follows: In 2002 early spawning/survey dates were 11 - 20 June; peak, 26 June - 13 July; and post-spawn 24 July - 7 August. In 2003, dates were separated as early, 25 May - 11 June; peak, 24 June - 8 July; and post-spawn, 1 - 16 August. The post-spawning surveys in late-July and August in both years were conducted after the majority of cutthroat trout had left tributary streams and returned to Yellowstone Lake.

Surveys were conducted from a small boat along the lake shoreline and on foot along tributary streams. Otter activity sites were identified by trails leading from water, bedding-down areas, presence of feces, and tracks (Bowyer et al. 1994, 1995, 2003; Ben-David et al. 1998). We considered a latrine site to be any site on which otters had deposited multiple feces. Surveys of tributaries began at the stream's mouth and continued upstream, where they were ceased $1 \mathrm{~km}$ past the last sign of otters or when fish were no longer visible in the channel.

Locations of otter activity sites were plotted on a digital map of Yellowstone Lake and tributary streams obtained from the 1:100,000-scale National Hydrography Dataset (NHD; USGS 2005) using ArcGIS 9 (ESRI, Redlands, CA). Length of stream and lakeshore surveyed were calculated in ArcMap by measuring distances between all sample locations using shoreline and streams as represented in the NHD. Total stream length surveyed was $64.7 \mathrm{~km}$ in 2002 and $104.4 \mathrm{~km}$ in 2003 . Total length of lake shoreline surveyed was $152.8 \mathrm{~km}$ in 2002 and 177.3 $\mathrm{km}$ in 2003.

At each site, numbers of old (deposited more than 24 hours before the survey) and fresh scats were recorded. The site was then cleared of all feces to avoid re-counting on return visits. GPS coordinates 
were recorded and small rock-cairns were placed to mark sites and assist in relocation. All latrine sites were re-visited between 2 and 5 times throughout the survey period to determine changes in otter activity and site characteristics. Fresh scats $(n=988)$ were bagged and frozen for later diet analyses. As we revisited some latrines more frequently than others, measures of fecal deposition rate were calculated as total number of scats counted on survey visits/number of survey visits.

Diet analyses.-A random sub-sample of otter scats $(n=515)$ from summer 2002 and 2003 was selected for diet analysis. Individual otter scats were soaked for 24-48 hours in a mixture of denture cleaner and water, and then agitated, to separate mucilaginous material from undigested prey remains (Jenkins et al. 1979; Conroy et al. 1993; Berg 1999). Samples were then washed through a series of finemeshed sieves (1.000 $\mathrm{mm}$ and $0.355 \mathrm{~mm}$ openings) and air dried for 48 hours. Cleaned samples were identified by comparing remains with keys of fish scales and/or bones (Lagler 1947; Casteel 1972, 1973, 1976; Cannon 1987; Wheeler and Jones 1989; Conroy et al. 1993; Oates et al. 1993; Daniels 1996), reptiles (Romer 1956), and amphibians (Duellman and Trueb 1986), as well as keys to bird feathers (Day 1966) and mammal hair (Day 1966; Moore et al. 1974). Comparisons were also made with prepared reference collections of known species from the study area, including cutthroat trout, lake trout, and longnose suckers caught in Yellowstone Lake. We identified fish prey to the family level, with the exception of the salmonids, for which attempts were made to distinguish cutthroat trout from lake trout. Additionally, a sub-sample of scats $(n=63)$ was sent to a professional identification laboratory (Pacific IDentifications Inc., Victoria, B.C.) for development of suitable techniques for differentiating between remains of the two salmonid species.

We recorded the frequency of occurrence of prey types for each sampling period (calculated as number of occurrences of a prey item/total number of scat samples; Erlinge 1968). Frequency of occurrence was then expressed as a percentage (Melquist and Hornocker 1983). A prey item was only counted if it occurred more than once in a sample (for example 2 scales of a fish would constitute presence of that species in the sample). When more than one individual of the same species appeared in a sample it was treated as a single occurrence (Melquist and Hornocker 1983).

Species-level identifications of Yellowstone cutthroat trout and lake trout were limited to a sub- sample of 110 scats. These samples included feces collected in both 2002 and 2003. Three constraints reduced the number of scats for these analyses. First, several key bones used for distinguishing trout species are present in fish heads, and otters often do not consume heads during feeding (J. Crait, pers. obs). Second, while vertebrae were found in most samples, many of them were not intact. Although noticeable differences do exist between cutthroat and lake trout vertebrae, differentiating between salmonid species based on these bones alone can be tenuous (Yang et al. 2004), and thus identifications were not attempted for vertebrae in poor condition. Finally, our reference collection did not include trout less than $27 \mathrm{~cm}$ in length. We were unable, therefore, to identify to species level any salmonids below this size.

Statistical analyses.-All statistical analyses were performed using SPSS for Windows 11.5. The Kolmogorov-Smironov test (Zar 1999) and Q-Q plots (Sokal and Rohlf 1995) were employed to test for normality, and Levene's test (Levene 1960) was used to test for homogeneity of variances. We used a Kruskal-Wallis test with multiple comparisons (Zar 1999) to test for differences in average fecal deposition rate at otter latrine sites across the three survey periods of early, peak, and post-spawn on Yellowstone Lake and tributary streams in 2002 and 2003. We then employed a Dunn test (Dunn 1964; Zar 1999) to test for differences in fecal deposition rate between the three sampling periods in 2002 and 2003. We used $95 \%$ confidence intervals (Jenkins et al. 1979), calculated from the binomial distribution (Zar 1999), to compare changes in percent occurrence of prey items throughout the cutthroat trout spawning period. For all statistical tests, significance was assumed at a level of $\alpha=0.05$.

\section{RESULTS}

During the summers of 2002 and 2003, we identified a total of 87 river otter latrine sites $(n=35$ on Yellowstone Lake and $n=52$ on tributary streams; Fig. 1). For the 2002 summer survey, fecal deposition rate at otter latrine sites (average number of feces per site) differed significantly across the three survey periods (early, peak, and post-cutthroat trout spawning) on tributary streams, while no significant difference was detected between survey periods on the Yellowstone Lake shoreline (KruskalWallis test; $\mathrm{df}=2, P=0.03$ for streams, $P=0.27$ for lake; Fig. 2). Pairwise comparisons showed that, in 2002 , fecal deposition rate was marginally lower on tributary streams in the post-spawning period $(1.33 \pm$ 
$0.76 \mathrm{feces} / \mathrm{site})$ than in the early spawning period $(6.25 \pm 2.00$ feces/site; Dunn test; $Q=2.37, k=3$; Fig. 2). For summer 2003, a significant difference in fecal deposition rate at latrines existed on both Yellowstone Lake and tributary streams across the three survey periods (Kruskal-Wallis test; $\mathrm{df}=2, P=$ 0.03 for both lake and streams; Fig. 2). Additionally, pairwise comparisons of the 2003 survey periods revealed significantly higher fecal deposition rates on tributary streams during the peak cutthroat spawning period than the post-spawning period (Dunn test; $Q=$ 2.62, $k=3$; Fig. 2). Conversely, fecal deposition rate was lower on the Yellowstone Lake shoreline during the 2003 peak-spawning period than the postspawning period (Dunn test; $Q=2.67, k=3$; Fig. 2).
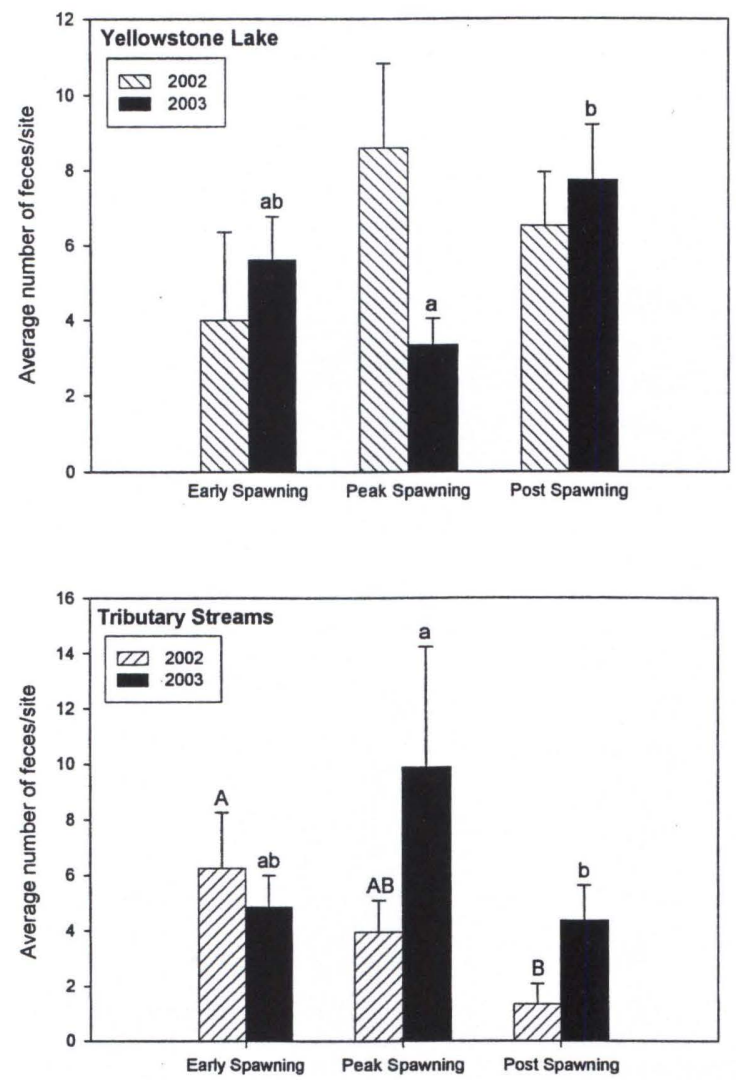

Fig. 2. Fecal deposition rate at river otter latrine sites on Yellowstone Lake and tributary streams, throughout the cutthroat trout spawning period, summer 2002 and 2003. Letters represent statistical difference at $a=0.05$ (Kruskal-Wallis and Dunn tests).

Fish were the primary food item found in otter scats throughout the study; present in $94 \%$ of the 515 analyzed samples (Table 1). Trout occurred in $72 \%$ of feces, while longnose suckers were found in $43 \%$ and minnows in $30 \%$ of total samples. In several instances more than one prey type was present in a sample. In addition, amphibians, primarily blotched tiger salamanders (Ambystoma tigrinum), were identified in $7 \%$ of otter feces, while birds and mammals constituted a negligible percentage of samples (birds $=3 \%$, mammals $=2 \%$; Table 1). Monthly occurrence of prey types on Yellowstone Lake and tributary streams is shown in Appendix A.

\begin{tabular}{|c|c|c|c|c|c|c|}
\hline \multirow[b]{2}{*}{ Food item } & \multicolumn{2}{|c|}{ Early Spawning } & \multicolumn{2}{|c|}{ Peak Spawning } & \multicolumn{2}{|c|}{ Post Spawning } \\
\hline & $\begin{array}{c}\text { No. of } \\
\text { occurrences }\end{array}$ & $\begin{array}{c}\text { Frequency } \\
(\%)\end{array}$ & $\begin{array}{c}\begin{array}{c}\text { No. of } \\
\text { occurrences }\end{array} \\
\end{array}$ & $\begin{array}{c}\text { Frequency } \\
(\%)\end{array}$ & $\begin{array}{c}\text { No. of } \\
\text { occurrences }\end{array}$ & $\begin{array}{c}\begin{array}{c}\text { Frequency } \\
(\%)\end{array} \\
\end{array}$ \\
\hline$\overline{\text { FISH }}$ & 170 & 98 & 180 & 96 & 136 & 89 \\
\hline Salmonidae & 139 & 80 & 145 & 77 & 86 & 56 \\
\hline $\begin{array}{l}\text { trout (Oncorhynchus } \\
\text { clarki bouvieri) }\end{array}$ & 42 & 24 & 49 & 26 & 14 & 9 \\
\hline Lake trout & & & & & & \\
\hline (Salvelinus namaycush ) & 2 & 1 & 1 & $<1$ & 2 & 1 \\
\hline Salmonidae & 95 & 55 & 95 & 51 & 70 & 46 \\
\hline $\begin{array}{l}\text { Catostomidae } \\
\text { (Catostomus }\end{array}$ & & & & & & \\
\hline catostomus) & 68 & 39 & 70 & 37 & 81 & 53 \\
\hline Cyprinidae (unidentified) & 64 & 37 & 56 & 30 & 33 & 22 \\
\hline $\begin{array}{l}\text { AMPHIBIANS } \\
\text { Blotched tiger salamander }\end{array}$ & 6 & 3 & 5 & 3 & 26 & 17 \\
\hline (Ambystoma tigrinum) & 5 & 3 & 2 & 1 & 13 & 8 \\
\hline Unidentified Anura & 1 & $<1$ & & & 1 & 1 \\
\hline BIRDS & 6 & 3 & 4 & 2 & 7 & 5 \\
\hline Anatidae (unidentified) & 2 & 1 & & & & \\
\hline Unidentified birds & 4 & 2 & & & & \\
\hline MAMMALS & 2 & 1 & 5 & 3 & 3 & 2 \\
\hline Muskrat (Ondatra sibethicus) & & & & & 1 & 1 \\
\hline Shrew (Sorer spp.) & & & 1 & $<1$ & & \\
\hline Unidentified mammals & & & & & & \\
\hline Total sample size & 174 & & 188 & & 153 & \\
\hline
\end{tabular}

Frequency of occurrence of prey items in otter feces changed throughout the summer (Fig. 3). On the Yellowstone Lake shoreline, trout remained the dominant prey item in otter scats during summer, but declined from $81 \%$ frequency of occurrence during early spawning to $65 \%$ at the end of the cutthroat spawning season. Frequency of occurrence of longnose suckers and minnows remained relatively steady between about $20 \%$ and $40 \%$ along the lake shoreline. In addition, prevalence of amphibians in Yellowstone Lake otter scats increased sharply late in the summer, climbing from 5\% occurrence during early and peak spawning to $22 \%$ occurrence at the end of cutthroat trout spawning. Finally, birds and mammals contributed little to otter scats along the lake shoreline throughout the summer, making up no more than $5 \%$ of samples. On tributary streams, frequency of occurrence of trout fell from a high of $79 \%$ during early cutthroat spawning to $43 \%$ during the post-spawning period. Trout were replaced by longnose suckers as the dominant prey item in tributary stream scats later in summer as suckers rose from a frequency of occurrence of $38 \%$ in the earlyspawning period to $67 \%$ by the end of cutthroat spawning; however, 95\% CIs for these two species overlapped in the post-spawning period (Fig. 3). 
Minnows were found in $27 \%$ to $37 \%$ of otter scats on tributary streams throughout the summer. The remaining tributary stream prey items reached highs of $10 \%$ for amphibians, $5 \%$ for birds, and $2 \%$ for mammals, all in the post-spawning period for cutthroat trout (Fig. 3).

Species-level identifications of Yellowstone cutthroat trout and lake trout were limited to 110 out of a total 370 scats containing salmonids. Cutthroat trout were found in 105 of the 110 samples. By contrast, we confirmed the presence of lake trout in only 5 of the 110 samples. Lake trout were found in four otter fecal samples collected on the Yellowstone Lake shoreline; two from the west side of the lake, near the Bridge Bay area, and one from the lake's Southeast Arm, collected in 2002, and one from the west side of the lake, near Pumice Point, collected in 2003. The other lake trout sample was collected in 2003 from the Arnica Creek lagoon, a tributary of Yellowstone Lake's West Thumb (Fig. 1).

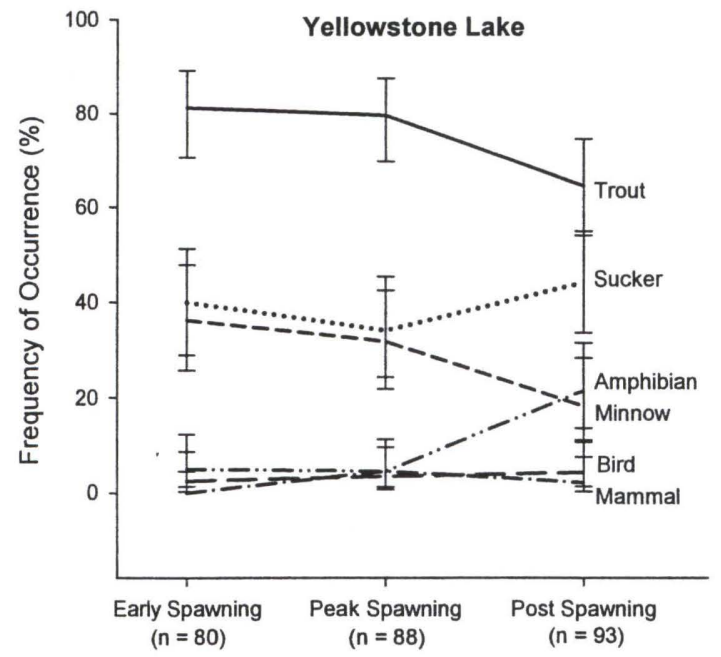

Fig. 3. Mean and $95 \%$ confidence intervals for frequency of occurrence of prey items in scats collected from river otter latrine sites on Yellowstone Lake and tributary streams throughout the cutthroat trout spawning period, summer 2002 and 2003.

\section{$\uparrow \quad$ DISCUSSION}

Yellowstone cutthroat trout are clearly the key prey of river otters in the Yellowstone Lake system during summer, suggesting that further cutthroat declines may have severe implications for the lake's otter population. Consistent with previous studies of otter feeding habits (Toweill 1974; Melquist and Hornocker 1983; Reid et al. 1994a, b; Melquist et al. 2003), otters around Yellowstone Lake appeared to follow the movements of spawning cutthroat trout. Indeed, while fluctuations existed in the proportion of other prey items in otter feces, the overall dominance of cutthroat trout in samples from both Yellowstone Lake and tributary streams was consistent throughout the study. Moreover, our diet studies indicate that Yellowstone Lake otters are unlikely to substitute introduced lake trout as an alternative prey base to a declining cutthroat trout population.

Fecal deposition rate at otter latrine sites varied with cutthroat trout spawning activity, indicating changes in otter activity in relation to prey movement. As hypothesized, there was a general trend towards increased otter use of spawning streams and decreased use of Yellowstone Lake during the height of spawning season, with a return to elevated otter activity on the lake after spawning had ended. This trend was stronger in 2003 than 2002; however, the 2002 measurements of fecal deposition rate should be viewed with caution as we did not have boat access to the lakeshore until mid-July. This limited our ability to document otter activity on much of Yellowstone Lake during early and peakspawning that year, and likely influenced the lack of significant difference in fecal deposition rate between spawning periods on the lake in 2002. In addition, due to limited access to spawning streams in late May and early June, our surveys did not capture the early spawning conditions on Arnica, Bridge, Clear, or Columbine Creeks in 2002. In 2003, when our surveys corresponded more closely with the spawning schedule of cutthroat trout, we observed the expected increase in otter activity on tributary streams, and concurrent decrease on the lakeshore, during peak spawning. In addition, fecal deposition rate on all tributary streams was significantly lower in the late summer (post-cutthroat spawning) period than for the middle (peak-spawning) period, in both 2002 and 2003. This also points to a seasonal switch in otter activity back to Yellowstone Lake in response to decreased availability of cutthroat trout in streams.

It should be noted that the use of fecal deposition rate as an index of otter activity has some limitations (Kruuk 1995). For example, scentmarking rates at latrine sites may increase during the spring breeding season (Rostain et al. 2004). While little information exists on otter breeding behavior in the Yellowstone Lake system, Melquist and Hornocker (1983) found that otters in Idaho remained in reproductive condition into May. Additionally, Zackheim (1982) suggested that breeding activity could have resulted in increased marking rates at latrines in southwestern Montana during April and May. Thus, it is possible that the lack of significant 
difference in fecal deposition rate between the "early" and "peak" cutthroat spawning periods was influenced by higher marking rates at the end of the breeding season. Nonetheless, increased marking rates in the breeding season should not differ between the Yellowstone Lake shoreline and tributary streams, thereby not affecting our comparisons of seasonal otter activity on the two water-types.

It is also possible that the location of feces at latrines on tributary streams or the Yellowstone Lake shoreline was not indicative of where otters consumed prey items. Davis (1992) reported average food transit time in river otters to be $202 \mathrm{~min}$, and Ormseth and Ben-David (2000) estimated total mean food retention times of $414-582 \mathrm{~min}$ in captive river otters. These findings imply that adequate time exists for otters to switch from lake to stream locations (or vice versa) between feeding and defecation. Indeed, in a study of Eurasian otters (Lutra lutra) feeding on salmonids, Durbin (1997) found that location of ingestion of trout and salmon was not related to site of defecation. Nonetheless, because otters may use scent marking to facilitate mutual avoidance (Melquist and Hornocker 1983; Ben-David et al., in press) or signal the use of food resources (Kruuk 1995), it is likely that otters concentrated their activity on tributary streams during the spawning period, leading to our observation of increased fecal deposition rate in relation to cutthroat trout distribution. It is also generally accepted that while sign surveys may not provide accurate abundance estimates for otters, they are useful indicators of otter distribution and activity (Melquist and Hornocker 1979; Melquist and Dronkert 1987; Swimley et al. 1998; Melquist et al. 2003; Bonesi and MacDonald 2004).

The preponderance of fish in scats collected from Yellowstone Lake and its tributary streams was consistent with findings from most studies of otter diet (Larivière and Walton 1998; Melquist et al. 2003). Otters are considered fish specialists (Melquist et al. 2003), and exceptions to this trend usually only occur in systems where otters feed heavily on crayfish (e.g., Grenfell 1974; Tumlison and Karnes 1987; Taylor et al. 2003). Crayfish do not occur in Yellowstone Lake or its tributary streams (Varley and Schullery 1998). Among fish families, salmonids were the dominant prey item in samples from both summers. Moreover, the overwhelming prevalence of cutthroat trout in scat samples identified to the species-level suggests that most trout in unidentified salmonid samples were cutthroats as well. Increased accessibility of spawning fish to otters was clearly demonstrated by seasonal changes in prey occurrence in scats from tributary streams. Trout dominated otter scats from May through July, a period that corresponds with the cutthroat trout spawning season (Jones et al. 1987; Gresswell and Varley 1988; Varley and Gresswell 1988; Gresswell et al. 1997). Trout were then replaced in the majority of otter scats from tributary streams by longnose suckers, a species which spawns towards the end of cutthroat trout spawning (Brown and Graham 1954). Reliance of otters on spawning fish has been documented in a number of other systems (Toweill 1974; Melquist and Hornocker 1983; Reid et al. 1994a, b; Melquist et al. 2003), and spawning season is often the only time when otters feed heavily on salmonids (Melquist et al. 2003). In Yellowstone Lake, however, cutthroat trout dominate fish abundance and biomass (Stapp and Hayward 2002a), and other than longnose suckers, are the only widely-distributed and accessible fish prey in the lake (Benson 1961; Kaeding et al. 1996; Varley and Schullery 1998). When not present in spawning streams, large, mature cutthroat trout inhabit Yellowstone Lake's littoral zone (Gresswell and Varley 1988). Their accessibility in these shallower waters is evident from the fact that, in our study, trout remained the primary food item in otter scats collected on the Yellowstone Lake shoreline throughout the summer. Additionally, some cutthroat trout remain residents in spawning streams and do not return to the lake for several years (Ball and Cope 1961; Varley and Gresswell 1988; Kelly 1993). Resident cutthroat could provide food for otters yearround and may explain why trout were still found in $43 \%$ of otter scats collected on tributaries in late summer, after cutthroat spawning had largely ended. Furthermore, while our study was conducted only during summer, the predominance of cutthroat trout, both in terms of availability in the Yellowstone Lake system and in otter scats collected from latrines on both water-types, suggests that Yellowstone cutthroat trout are likely the key prey for the lake's river otter population throughout the year.

Though not as prevalent in scat samples as cutthroat trout, longnose suckers also appeared to contribute significantly to the diet of river otters in our study. Because they attain large sizes (Baxter and Stone 1995) and are more easily caught than salmonids (Melquist et al. 2003), suckers are frequently documented in otter diet studies (Melquist et al. 2003), and, in some systems, constitute the main prey of otters (e.g., Knudsen and Hale 1968; Zackheim 1982; Serfass et al. 1990; Reid et al. 1994a; Berg 1999). In our study, otters along tributary streams responded to declining cutthroat trout spawning, and initiation of sucker spawning, 
with increased feeding on suckers later in summer. Nonetheless, trout remained more prevalent in scat samples collected from the Yellowstone Lake shoreline throughout the summer, suggesting that otters opportunistically prey on suckers when they are spawning but preferentially feed on cutthroat trout when both fish species are similarly accessible in the lake's littoral zone. This conclusion is further supported by the observation that although longnose suckers were available to otters on tributary streams in late summer, and their consumption increased during that time, otter activity shifted back to Yellowstone Lake following the movements of cutthroat trout.

Finally, while longnose suckers constituted a sizeable portion of the diet of otters in late summer, they are unlikely to act as a suitable replacement for cutthroat trout. Suckers are not as abundant as cutthroat trout in Yellowstone Lake (Stapp and Hayward 2002a), nor do they provide the energetic returns of lipid-rich trout (Hanson et al. 1997; Ruzycki et al. 2003). Furthermore, peak spawning migrations of cutthroat trout from Yellowstone Lake likely coincide with the otter pup-rearing period (Melquist and Dronkert 1987; Varley 1998). During this time, spawning cutthroat trout provide an accessible, energy-rich prey for feeding and development of foraging skills in otter pups. By contrast, late-summer spawning runs of longnose suckers provide limited benefits to family groups of otters during the pup-rearing period.

Minnows, although present in feces collected from latrine sites throughout the summer, occurred infrequently. While otter predation on minnows has been reported in previous studies (Melquist et al. 2003), their limited distribution in Yellowstone Lake (Benson 1961; Kaeding et al. 1996) and their small size (Baxter and Stone 1995; Varley and Schullery 1998) make it unlikely that minnows are an important prey item for otters at any time during the year. It is important to note that minnows, as well as small trout and suckers, may be overrepresented in diet analyses due to secondary consumption of prey remains (Carss and Parkinson 1996). Counts of secondary consumption arise when an otter feeds on a piscivorous fish, which has the remains of another fish in its stomach. In diet analyses of scat samples, bones and scales of the prey-fish may be present, and are usually counted as if having been preyed upon by the otter (Carss and Parkinson 1996). Indeed, a number of otter scats collected in our study contained bones and scales of small fish as well as large trout and suckers. Nonetheless, in Yellowstone Lake longnose suckers primarily feed on vegetation and zooplankton (Varley and Schullery 1998), and cutthroat trout are rarely piscivorous (Greswell 1995), instead consuming a variety of macroinvertebrates and aquatic insects (Gresswell and Varley 1988; Gresswell et al. 1997). This suggests that our rate of overestimation of prey items in otter feces resulting from secondary consumption was low. Moreover, frequency of occurrence in otter scats is sufficiently rigorous for ranking the importance of key prey items (Erlinge 1968; Carss and Parkinson 1996), which was ultimately the goal of our diet analyses.

The presence of non-fish prey was limited in otter scats throughout most of our study. An exception was the late-summer increase of amphibians (primarily blotched tiger salamanders) in scats collected at latrines along the Yellowstone Lake shore. Otters likely increase predation on salamanders in warmer months when these prey become active and migrate in large numbers to breeding sites (Koch and Peterson 1995; Melquist et al. 2003). Wuerthner (1992) reported otters feeding on abundant salamanders in other areas of YNP. Additionally, salamanders are occasionally sympatric with minnows in lagoons and other shallow waters, but they are rarely found in areas containing trout (Varley and Schullery 1998). Thus accelerated feeding on salamanders may be indicative of reduced availability of trout as otters increase foraging in areas containing smaller, less energy-rich prey. Interestingly, salamanders are considered uncommon around Yellowstone Lake (Patla and Peterson 2002), but were more prevalent in otter feces than more widespread amphibians such as Columbia spotted frogs (Rana luteiventris). This suggests that salamanders are easier for otters to catch than more agile frogs. The rare occurrence of birds and mammals in otter scats from Yellowstone was consistent with most studies of otter feeding behavior (Melquist et al. 2003). Birds may be taken opportunistically and primarily include aquatic birds that are unable to fly due to injury or molting (Melquist et al. 2003). Similarly, mammals are probably incidental prey of river otters. Muskrats (Ondatra zibethicus) are the likeliest mammalian prey of river otters in most habitats (Melquist et al. 2003), and this appeared to be the case in the Yellowstone Lake system as well.

The heavy dependence of river otters on cutthroat trout documented in our study indicates that dwindling numbers of these fish may be detrimental to Yellowstone Lake's otter population. Indeed, we found little evidence that otters could switch to feeding on introduced lake trout as a replacement 
salmonid prey. Lake trout were rare in the scats we collected; suggesting that these fish are likely incidental captures and that otter predation on lake trout in the Yellowstone Lake system is uncommon. Studies in other regions where otters and lake trout co-exist have found that these fish were completely absent in the diet of otters (Sheldon and Toll 1964; Reid et al. 1994a). Reid et al. (1994a) reported that in northeastern Alberta, lake trout were the only potentially available fish species not present in otter scats, and attributed this to lake trout inhabiting deep water. In Yellowstone Lake, mature lake trout are found in shallower water for a brief period after the spring breakup and melting of the lake's ice cover (P. Bigelow, pers. comm). Nonetheless, we found no evidence of increased otter predation on lake trout during this time, even in the West Thumb portion of the lake where the majority of lake trout are thought to occur (Koel et al., in press). Thus, it is unlikely that otters feed extensively on lake trout during any season.

Yellowstone Lake's otters are unique in that they primarily rely on one species of trout for meeting their energetic demands - a phenomenon which probably occurs throughout the year. Indeed, thermal influences in Yellowstone Lake (Morgan et al. 2003) maintain ice-free sections of water and ensure that otters have access to lipid-rich cutthroat trout, even during energetically-demanding winter months (Varley and Schullery 1998). Therefore, the present threats to these native fish (Koel et al. 2004; Koel et al., in press) should raise concern for the viability of the Yellowstone Lake otter population. A decline in this piscivorous predator may have permeating effects through the Yellowstone Lake ecosystem. Growing evidence suggests that semiaquatic predators, such as otters, link systems by transporting aquatically-derived nutrients to terrestrial landscapes (Ben-David et al. 1998; Polis et al. 2004), and that these linkages can be disrupted by introduced fish species (Baxter et al. 2004; Dunham et al. 2004). We recently documented that otters transport lake-derived nutrients to terrestrial vegetation around Yellowstone Lake and that these nutrients influence the prevalence and growth of plants (Crait 2005). The high reliance of otters on cutthroat trout, therefore suggests that a decline of these fish may have propagating effects beyond Yellowstone Lake itself, into riparian forests.

\section{ACKNOWLEDGMENTS}

We thank J. R. Boyd, R. G. Eddy, K. E. Ott, and S. R. Schaefer for assistance in data collection and laboratory analyses. R. Landis and W. Wengeler shared important information on otter survey strategies for Yellowstone Lake. We are grateful to N. P. Nibbelink for assistance with GIS analyses. S. W. Buskirk and E. G. Pendall provided insight and valuable comments on earlier versions of this manuscript. We thank Yellowstone National Park, especially P. E. Bigelow, B. D. Ertel, T. M. Koel, D. L. Mahony, and J. D. Varley, for sharing data and assisting with logistics. Funding for this study was provided by EPA-STAR grant R829426 awarded to R. O. Hall and M. Ben-David, the UW-NPS Research Center, and the Department of Zoology and Physiology at the University of Wyoming.

\section{LiteratURE CITED}

Ball, O. P., and O. B. Cope. 1961. Mortality studies on cutthroat trout in Yellowstone Lake. U.S. Fish and Wildlife Service, Research Paper 55.

Baxter, C. V., K. D. Fausch, M. Murakami, and P. L. Chapman. 2004. Fish invasion restructures stream and forest food webs by interrupting reciprocal prey subsidies. Ecology 85:26562663.

Baxter, G. T., and M. D. Stone. 1995. Fishes of Wyoming. Wyoming Game and Fish Department, USA.

Ben-David, M., G. Blundell, J. Kern, J. Maier, E. Brown, and $S$. Jewett. In press. Communication in river otters: creation of variable resource sheds for terrestrial communities. Ecology.

Ben-David, M., R. T. Bowyer, L. K. Duffy, D. D. Roby, and D. M. Schell. 1998. Social behavior and ecosystem processes: river otter latrines and nutrient dynamics of terrestrial vegetation. Ecology 79:25672571.

Ben-David, M., T. M. Williams, and O. A. Ormseth. 2000. Effects of oiling on exercise physiology and diving behavior of river otters: a captive study. Canadian Journal of Zoology 78:1380-1390.

Benson, N. G. 1961. Limnology of Yellowstone Lake in relation to the cutthroat trout. U. S. Department of the Interior Fish and Wildlife Service. U. S. Fish and Wildlife Service Research Report 56, Yellowstone Lake trout studies: 1-33. 
Berg, J. K. 1999. River otter research project on the upper Colorado River basin in and adjacent to Rocky Mountain National Park, Colorado. Rocky Mountain National Park.

Blundell, G. M., M. Ben-David, and R. T. Bowyer. 2002. Sociality in river otters: cooperative foraging or reproductive strategies? Behavioral Ecology 13:134-141.

Bonesi, L., and D. W. MacDonald. 2004. Evaluation of sign surveys as a way to estimate the relative abundance of American mink (Mustela vison). Journal of Zoology 262:6572 .

Bowyer, R. T., G. M. Blundell, M. Ben-David, S. C. Jewett, T. A. Dean, and L. K. Duffy. 2003. Effects of the Exxon Valdez oil spill on river otters: injury and recovery of a sentinel species. Wildlife Monographs:1-53.

Bowyer, R. T., J. W. Testa, and J. B. Faro. 1995. Habitat selection and home ranges of river otters in a marine environment: effects of the Exxon Valdez oil spill. Journal of Mammalogy 76:1-11.

Bowyer, R. T., J. W. Testa, J. B. Faro, C. C. Schwartz, and J. B. Browning. 1994. Changes in diets of river otters in Prince William Sound, Alaska: effects of the Exxon Valdez oil spill. Canadian Journal of Zoology 72:970-976.

Brown, C. J. D., and R. J. Graham. 1954. Observations on the longnose sucker in Yellowstone Lake. Transactions of the American Fisheries Society 83:38-46.

Buskirk, S. W. 1999. Mesocarnivores of Yellowstone. Pp. 165-187 in Carnivores in ecosystems: the Yellowstone experience ( $\mathrm{T}$. W. Clark, A. P. Curlee, S. C. Minta and P. M. Kareiva, eds.). Yale University Press, New Haven.

Cannon, D. Y. 1987. Marine fish osteology: a manual for archaeologists. Vol. Publication no. 18. Archaeology Press, Simon Fraser University, Burnaby, B.C.

Carss, D. N., and S. G. Parkinson. 1996. Errors associated with otter Lutra lutra faecal analysis. I. Assessing general diet from spraints. Journal of Zoology 238:301-317.
Casteel, R. W. 1972. A key, based on scales, to the families of native California freshwater fishes. Proceedings of the California Academy of Sciences 39:75-86.

Casteel, R. W. 1973. The scales of the native freshwater fish families of Washington. Northwest Science 47:230-238.

Casteel, R. W. 1976. Fish remains in archaeology and paleo-environmental studies. Academic Press, London.

Conroy, J. W. H., J. Watt, J. B. Webb, and A. Jones. 1993. A guide to the identification of prey remains in otter spraint. An Occasional Publication of the Mammal Society No. 16: 52.

Crait, J. R. 2005. Seasonal activity and nutrient transport by river otters in Yellowstone National Park. M.S. Thesis, University of Wyoming, Laramie.

Daniels, R. A. 1996. Guide to the identification of scales of inland fishes of northeastern North America. New York State Museum, Research Paper New York State Museum Bulletin No. 488.

Davenport, M. B. 1974. Piscivorous avifauna on Yellowstone Lake, Yellowstone National Park. National Park Service: 62 pp.

Davis, H. G., R. J. Aulerich, S. J. Bursian, J. G. Sikarskie, and J. N. Stuht. 1992. Feed consumption and food transit time in northern river otters (Lutra canadensis). Journal of Zoo and Wildlife Medicine $23: 241-244$.

Day, M. G. 1966. Identification of hair and feather remains in the gut and faeces of stoats and weasels. Journal of Zoology 148:201-217.

Despain, D. G. 1990. Yellowstone vegetation: consequences of environment and history in a natural setting. Roberts Rinehart Publishers, Boulder, CO.

Duellman, W. E., and L. Trueb. 1986. Biology of amphibians. McGraw-Hill, Inc, New York. 
Dunham, J. B., D. S. Pilliod, and M. K. Young. 2004. Assessing the consequences of nonnative trout in headwater ecosystems in western North America. Fisheries 29:18-26.

Dunn, O. J. 1964. Multiple contrasts using rank sums. Technometrics 6:241-252.

Durbin, L. S. 1997. Composition of salmonid species in the estimated diet of otters (Lutra lutra) and in electrofishing catches. Journal of Zoology 243:821-825.

Erlinge, S. 1968. Food studies on captive otters Lutra lutra L. Oikos 19:259-270.

Felicetti, L. A., C. C. Schwartz, R. O. Rye, K. A. Gunther, J. G. Crock, M. A. Haroldson, L. Waits, and C. T. Robbins. 2004. Use of naturally occurring mercury to determine the importance of cutthroat trout to Yellowstone grizzly bears. Canadian Journal of Zoology 82:493-501.

Grenfell, W. E., Jr. 1974. Food habits of the river otter in Suisun Marsh, central California. M.S. Thesis, California State University, Sacramento.

Gresswell, R. E. 1995. Yellowstone cutthroat trout. Pp. 36-54 in Conservation assessment for inland cutthroat trout (M. K. Young, ed.). US Forest Service General Technical Report RM-GTR-256.

Gresswell, R. E., and W. J. Liss. 1995. Values associated with management of Yellowstone cutthroat trout in Yellowstone National Park. Conservation Biology 9:159-165.

Gresswell, R. E., W. J. Liss, and G. L. Larson. 1994. Life-history organization of Yellowstone cutthroat trout (Oncorhynchus clarki bouvieri) in Yellowstone Lake. Canadian Journal of Fisheries and Aquatic Sciences 51 (Suppl. 1):298-309.

Gresswell, R. E., W. J. Liss, G. L. Larson, and P. J. Bartlein. 1997. Influence of basin-scale physical variables on life history characteristics of cutthroat trout in Yellowstone Lake. North American Journal of Fisheries Management 17:1046-1064.
Gresswell, R. E., and J. D. Varley. 1988. Effects of a century of human influence on the cutthroat trout of Yellowstone Lake. American Fisheries Society Symposium 4:45-52.

Hanson, P. C., T. B. Johnson, D. E. Schindler, and J. F. Kitchell. 1997. Fish bioenergetics 3.0. University of Wisconsin, Sea Grant Institute, Research Paper Technical Report WISCU-T-97-001.

Jenkins, D., J. G. K. Walker, and D. McCowan. 1979. Analyses of otter (Lutra lutra) faeces from Deeside, N.E. Scotland. Journal of Zoology 187:235-244.

Johnson, K. A., and R. L. Crabtree. 1999. Small prey of carnivores in the Greater Yellowstone Ecosystem. Pp. 239-263 in Carnivores in ecosystems: the Yellowstone experience ( $\mathrm{T}$. W. Clark, A. P. Curlee, S. C. Minta and P. M. Kareiva, eds.). Yale University Press, New Haven.

Jones, R. D., D. G. Carty, R. E. Gresswell, C. J. Hudson, and D. L. Mahony. 1987. Fishery and aquatic management program in Yellowstone National Park. U.S. Fish and Wildlife Service, Research Paper Technical Report 1986.

Kaeding, L. R. 2002. Factors influencing the distribution of American white pelicans foraging on the Yellowstone River, Yellowstone National Park, USA. Waterbirds 25:305-311.

Kaeding, L. R., G. D. Boltz, and D. G. Carty. 1996. Lake trout discovered in Yellowstone Lake threaten native cutthroat trout. Fisheries $21: 16-20$.

Kaplinski, M. A. 1991.Geomorphology and geology of Yellowstone Lake, Yellowstone National Park, Wyoming. M.S. Thesis, Northern Arizona University, Flagstaff.

Kelly, B. M. 1993. Ecology of Yellowstone cutthroat trout and an evaluation of potential effects of angler wading in the Yellowstone River. M.S. Thesis, Montana State University, Bozeman. 
Knight, D. H. 1994. Mountains and plains: the ecology of Wyoming landscapes. Yale University Press, New Haven.

Knudsen, G. J., and J. B. Hale. 1968. Food habits of otters in the Great Lakes region. Journal of Wildlife Management 32:89-\&.

Koch, E. D., and C. R. Peterson. 1995. Amphibians $\&$ reptiles of Yellowstone and Grand Teton National Parks. University of Utah Press, Salt Lake City, UT.

Koel, T. M., J. L. Arnold, P. E. Bigelow, P. D. Doepke, B. D. Ertel, and D. L. Mahony. 2004. Yellowstone Fisheries and Aquatic Sciences: Annual Report, 2003. National Park Service, Yellowstone Center for Resources, Research Paper YCR-NR-200403.

Koel, T. M., P. E. Bigelow, P. D. Doepke, B. D. Ertel, and D. L. Mahony. In Press. Nonnative lake trout result in Yellowstone cutthroat decline and impacts to bears and anglers. Fisheries.

Kruuk, H. 1995. Wild otters: predation and populations. Oxford University Press, Oxford.

Lagler, K. F. 1947. Scale characters of the families of Great Lakes fishes. Transactions of the American Microscopical Society 66:149171.

Lagler, K. F., and B. T. Ostenson. 1942. Early spring food of the otter in Michigan. Journal of Wildlife Management 6:244-254.

Larivière, S., and L. R. Walton. 1998. Lontra canadensis. Mammalian Species:1-8.

Levene, H. 1960. Robust tests for equality of variances. Pp. 278-292 in Contributions to probability and statistics: essays in honor of Harold Hotelling (I. Olkin, S. G. Ghurye, W. Hoeffding, W. G. Madow and H. B. Mann, eds.). Stanford University Press, Stanford, CA.

Marston, R. A., and J. E. Anderson. 1991. Watersheds and vegetation of the Greater Yellowstone Ecosystem. Conservation Biology 5:338-346.
Mattson, D. J., B. M. Blanchard, and R. R. Knight. 1991. Food habits of Yellowstone grizzly gears, 1977-1987. Canadian Journal of Zoology 69:1619-1629.

Mattson, D. J., and D. P. Reinhart. 1995. Influences of cutthroat trout (Oncorhynchus clarki) on behaviour and reproduction of Yellowstone grizzly bears (Ursus arctos), 1975-1989. Canadian Journal of Zoology 73:2072-2079.

McEneaney, T. 2002. Piscivorous birds of Yellowstone Lake: their history, ecology, and status. Pp. 121-134 in Yellowstone Lake: hotbed of chaos or reservoir of resilience? Proceedings of the 6 th Biennial Scientific Conference on the Greater Yellowstone Ecosystem (R. J. Anderson and D. Harmon, eds.). Yellowstone Center for Resources and the George Wright Society.

McIntyre, J. D. 1995. Review and assessment of possibilities for protecting the cutthroat trout of Yellowstone Lake from introduced lake trout: proceedings of a workshop and information exchange held in Gardiner, Montana, February 15-17, 1995. Pp. 28-33 in The Yellowstone Lake crisis: confronting a lake trout invasion. A report to the director of the National Park Service (J. D. Varley and P. Schullery, eds.). Yellowstone Center for Resources, National Park Service, Yellowstone National Park, Wyoming.

Melquist, W. E., and A. E. Dronkert. 1987. River otter. Pp. 625-641 in Wild furbearer management and conservation in North America (M. Novak, J. A. Baker, M. E. Obbard and B. Malloch, eds.). Ontario Trappers Association, North Bay, Ontario.

Melquist, W. E., and M. G. Hornocker. 1979. Methods and techniques for studying and censusing river otter populations. Forest, Wildlife and Range Experiment Station, Research Paper Technical Report 8: 17 pp.

Melquist, W. E., and M. G. Hornocker. 1983. Ecology of river otters in west central Idaho. Wildlife Monographs 83:1-60. 
Melquist, W. E., P. J. Polechla, Jr., and D. Toweill. 2003. River otter: Lontra canadensis. Pp. 708-734 in Wild mammals of North America: biology, management, and conservation (G. A. Feldhamer, B. C. Thompson and J. A. Chapman, eds.). Johns Hopkins University Press, Baltimore, MD.

Moore, T. D., L. E. Spence, C. E. Dugnolle, and W. G. Hepworth, Editor. 1974. Identification of the dorsal guard hairs of some mammals of Wyoming. Wyoming Game and Fish Department, Research Paper Bulletin No. 14.

Morgan, L. A., W. C. Shanks, D. A. Lovalvo, S. Y. Johnson, W. J. Stephenson, K. L. Pierce, S. S. Harlan, C. A. Finn, G. Lee, M. Webring, B. Schulze, J. Duhn, R. Sweeney, and L. Balistrieri. 2003. Exploration and discovery in Yellowstone Lake: results from highresolution sonar imaging, seismic reflection profiling, and submersible studies. Journal of Volcanology and Geothermal Research 122:221-242.

Oates, D. W., L. M. Krings, and K. L. Ditz. 1993. Field manual for the identification of selected North American freshwater fish by fillets and scales. Nebraska Game and Parks Commission, Research Paper Nebraska Technical Series Number 19.

Ormseth and Ben-David. 2000. Ingestion of oil hydrocarbons: effects on digesta retention times and nutrient uptake in captive river otters. Journal of Comparative Physiology B. 170: 419-428.

Patla, D. A., and C. R. Peterson. 2002. Amphibian diversity, distribution, and habitat use in the Yellowstone Lake basin. Pp. 179-191 in Yellowstone Lake: hotbed of chaos or reservoir of resilience? Proceedings of the 6th Biennial Scientific Conference on the Greater Yellowstone Ecosystem (R. J. Anderson and D. Harmon, eds.). Yellowstone Center for Resources and the George Wright Society.

Polis, G. A., M. E. Power, and G. R. Huxel. 2004. Food webs at the landscape level. The University of Chicago Press, Chicago, IL.
Pritchard, G. T., and C. T. Robbins. 1990. Digestive and metabolic efficiencies of grizzly and black bears. Canadian Journal of Zoology 68:1645-1651.

Quist, M. C., and W. A. Hubert. 2004. Bioinvasive species and the preservation of cutthroat trout in the western United States: ecological, social, and economic issues. Environmental Science \& Policy 7:303-313.

Reid, D. G., T. E. Code, A. C. H. Reid, and S. M. Herrero. 1994a. Food habits of the river otter in a boreal ecosystem. Canadian Journal of Zoology 72:1306-1313.

Reid, D. G., T. E. Code, A. C. H. Reid, and S. M. Herrero. 1994b. Spacing, movements, and habitat selection of the river otter in boreal Alberta. Canadian Journal of Zoology 72:1314-1324.

Reinhart, D. P., M. A. Haroldson, D. J. Mattson, and K. A. Gunther. 2001. Effects of exotic species on Yellowstone's grizzly bears. Western North American Naturalist 61:277288.

Reinhart, D. P., and D. J. Mattson. 1990. Bear use of cutthroat trout spawning streams in Yellowstone National Park. Pp. 343-350 in Bears - their biology and management: proceedings of the 8th International Conference on Bear Research and Management, 20-25 February 1989, Victoria, British Columbia (L. M. Darling and W. R. Archibald, eds.). International Association for Bear Research and Management.

Romer, A. S. 1956. Osteology of the reptiles. The University of Chicago Press, Chicago, IL.

Rostain, R. R., M. Ben-David, P. Groves, and J. A. Randall. 2004. Why do river otters scentmark? An experimental test of several hypotheses. Animal Behaviour 68:703-711.

Ruzycki, J. R., D. A. Beauchamp, and D. L. Yule. 2003. Effects of introduced lake trout on native cutthroat trout in Yellowstone Lake. Ecological Applications 13:23-37. 
Ryder, R. A. 1955. Fish predation by the otter in Michigan. Journal of Wildlife Management 19:497-498.

Schullery, P., and J. D. Varley. 1995. Cutthroat trout and the Yellowstone Lake ecosystem. Pp. 12-21 in The Yellowstone Lake crisis: confronting a lake trout invasion. A report to the director of the National Park Service (J. D. Varley and P. Schullery, eds.). Yellowstone Center for Resources, National Park Service, Yellowstone National Park, Wyoming.

Serfass, T. L., L. M. Rymon, and R. P. Brooks. 1990. Feeding relationships of river otters in northeastern Pennsylvania. Transactions of the Northeast Section of the Wildlife Society 47:43-53.

Sheldon, W. G., and W. G. Toll. 1964. Feeding habits of the river otter in a reservoir in central Massachusetts. Journal of Mammalogy 45:449-455

Sokal, R. R., and F. J. Rohlf. 1995. Biometry: the principles and practice of statistics in biological research. 3rd ed. W. H. Freeman and Company, New York.

Stapp, P., and G. D. Hayward. 2002a. Estimates of predator consumption of Yellowstone cutthroat trout (Oncorhynchus clarki bouvieri) in Yellowstone Lake. Journal of Freshwater Ecology 17:319-329.

Stapp, P., and G. D. Hayward. 2002b. Effects of an introduced piscivore on native trout: insights from a demographic model. Biological Invasions 4:299-316.

Stewart, D. J., D. Weininger, D. V. Rottiers, and T. A. Edsall. 1983. An energetics model for lake trout (Salvelinus namaycush): application to the Lake Michigan population. Canadian Journal of Fisheries and Aquatic Sciences 40:681-698.

Swenson, J. E. 1978. Prey and foraging behavior of ospreys on Yellowstone Lake, Wyoming. Journal of Wildlife Management 42:87-90.

Swenson, J. E., K. L. Alt, and R. L. Eng. 1986. Ecology of bald eagles in the Greater Yellowstone Ecosystem. Wildlife Monographs:1-46.
Swimley, T. J., T. L. Serfass, R. P. Brooks, and W. M. Tzilkowski. 1998. Predicting river otter latrine sites in Pennsylvania. Wildlife Society Bulletin 26:836-845.

Taylor, M., J. E. Rettig, and G. R. Smith. 2003. Diet of re-introduced river otters, Lontra canadensis, in north-central Arizona. Journal of Freshwater Ecology 18:337-338.

Toweill, D. E. 1974. Winter food habits of river otters in western Oregon. Journal of Wildlife Management 38:107-111.

Tumlison, R., and M. Karnes. 1987. Seasonal changes in food habits of river otters in southwestern Arkansas beaver swamps. Mammalia 51:225-231.

(USGS), U. S. G. S. 2005. National Hydrography Dataset (NHD). http://nhd.usgs.gov/.

Varley, J. D., and R. E. Gresswell. 1988. Ecology, status, and management of the Yellowstone cutthroat trout. American Fisheries Society Symposium 4:13-24.

Varley, J. D., and P. Schullery. 1995. Socioeconomic values associated with the Yellowstone Lake cutthroat trout. Pp. 22-27 in The Yellowstone Lake crisis: confronting a lake trout invasion. A report to the director of the National Park Service (J. D. Varley and P. Schullery, eds.). Yellowstone Center for Resources, Yellowstone National Park, Wyoming, USA.

Varley, J. D., and P. Schullery. 1996. Yellowstone lake and its cutthroat trout in Science and Ecosystem Management in the National Parks (W. L. Halvorson and G. E. Davis, eds.). University of Arizona Press, Tucson, AZ.

Varley, J. D., and P. Schullery. 1998. Yellowstone fishes: ecology, history, and angling in the park. Stackpole Books, Mechanicsburg, PA.

Varley, N. 1998. Yellowstone's river otters: enigmatic water weasels. Yellowstone Science 6:15-18.

Wheeler, A., and A. K. G. Jones. 1989. Fishes. Cambridge University Press, Cambridge. 
Wuerthner, G. 1992. Yellowstone: a visitor's companion. Stackpole Books, Harrisburg, PA.

Yang, D. Y. Y., A. Cannon, and S. R. Saunders. 2004. DNA species identification of archaeological salmon bone from the Pacific Northwest Coast of North America. Journal of Archaeological Science 31:619-631.
Zackheim, H. 1982. Ecology and population status of the river otter in southwestern Montana. M.S. Thesis, University of Montana, Missoula.

Zar, J. H. 1999. Biostatistical analysis, 4th ed. Prentice Hall, Upper Saddle River, NJ. 
APPENDIX A.-Monthly occurrence of prey items of river otters based on 515 scats collected from latrine sites on Yellowstone Lake and tributary streams, summer 2002 and 2003.

\begin{tabular}{|c|c|c|c|c|c|c|}
\hline \multirow[b]{2}{*}{ Food item } & \multicolumn{2}{|c|}{ May } & \multicolumn{2}{|c|}{ June } & \multicolumn{2}{|c|}{ July } \\
\hline & $\begin{array}{c}\text { No. of } \\
\text { occurrences }\end{array}$ & $\begin{array}{l}\text { Frequency } \\
(\%)\end{array}$ & $\begin{array}{c}\text { No. of } \\
\text { occurrences }\end{array}$ & $\begin{array}{c}\text { Frequency } \\
(\%)\end{array}$ & $\begin{array}{c}\text { No. of } \\
\text { occurrences }\end{array}$ & $\begin{array}{c}\text { Frequenc) } \\
(\%)\end{array}$ \\
\hline$\overline{\mathrm{FISH}}$ & 40 & 100 & 194 & 96 & 140 & 97 \\
\hline Salmonidae & 37 & 93 & 156 & 77 & 105 & 73 \\
\hline $\begin{array}{l}\text { Yellowstone cutthroat trout } \\
\text { (Oncorhynchus clarki bouvieri) } \\
\text { Lake trout }\end{array}$ & 18 & 45 & 41 & 20 & 34 & 24 \\
\hline (Salvelinus namaycush) & 1 & 3 & 1 & $<1$ & 2 & 1 \\
\hline Unidentified Salmonidae & 18 & 45 & 114 & 56 & 69 & 48 \\
\hline $\begin{array}{l}\text { Catostomidae } \\
\text { Longnose sucker } \\
\text { (Catostomus catostomus) }\end{array}$ & 15 & 38 & 76 & 37 & 64 & 44 \\
\hline Cyprinidae (unidentified) & 18 & 45 & 65 & 32 & 40 & 28 \\
\hline $\begin{array}{l}\text { AMPHIBIANS } \\
\text { Blotched tiger salamander }\end{array}$ & 1 & 3 & 7 & 3 & 7 & 5 \\
\hline $\begin{array}{l}\text { (Ambystoma tigrinum ) } \\
\text { Unidentified Anura }\end{array}$ & 1 & 3 & $\begin{array}{l}4 \\
1\end{array}$ & $\begin{array}{c}2 \\
<1\end{array}$ & 4 & 3 \\
\hline $\begin{array}{l}\text { BIRDS } \\
\text { Anatidae (unidentified) } \\
\text { Unidentified birds }\end{array}$ & 0 & & $\begin{array}{l}7 \\
1 \\
6\end{array}$ & $\begin{array}{c}3 \\
<1 \\
3\end{array}$ & 3 & 2 \\
\hline $\begin{array}{l}\text { MAMMALS } \\
\text { Muskrat (Ondatra zibethicus) } \\
\text { Shrew (Sorex spp.) } \\
\text { Unidentified mammals }\end{array}$ & 0 & & 5 & 2 & $\begin{array}{l}2 \\
1\end{array}$ & 1 \\
\hline Total sample size & 40 & & 203 & & 144 & \\
\hline
\end{tabular}

